\title{
Addiction to Runx1 is partially attenuated by loss of p53 in the Ep-Myc lymphoma model
}

\author{
Gillian Borland ${ }^{1, *}$, Anna Kilbey ${ }^{1, *}$, Jodie Hay ${ }^{1}$, Kathryn Gilroy ${ }^{1}$, Anne Terry ${ }^{1}$, Nancy \\ Mackay ${ }^{1}$, Margaret Bell ${ }^{2}$, Alma McDonald ${ }^{1}$, Ken Mills ${ }^{3}$, Ewan Cameron² and James \\ C. Neil ${ }^{1}$ \\ ${ }^{1}$ Molecular Oncology Laboratory, Institute of Infection, Immunity and Inflammation, University of Glasgow, Glasgow, UK \\ 2 School of Veterinary Medicine, University of Glasgow, Glasgow, UK \\ ${ }^{3}$ Centre for Cancer Research and Cell Biology, Queen's University Belfast, Belfast, UK \\ * Joint first authors \\ Correspondence to: James C. Neil, email: James.Neil@glasgow.ac.uk \\ Ewan Cameron, email: Ewan.Cameron@glasgow.ac.uk
}

Keywords: Runx 1, lymphoma, myc, oncogene addiction

Received: February 19, $2016 \quad$ Accepted: March 28, $2016 \quad$ Published: April 02, 2016

\section{ABSTRACT}

The Runx genes function as dominant oncogenes that collaborate potently with Myc or loss of p53 to induce lymphoma when over-expressed. Here we examined the requirement for basal Runx1 activity for tumor maintenance in the EH-Myc model of Burkitt's lymphoma. While normal Runx ${ }^{f / f l}$ lymphoid cells permit mono-allelic deletion, primary $\mathrm{E} \mu-\mathrm{Myc}$ lymphomas showed selection for retention of both alleles and attempts to enforce deletion in vivo led to compensatory expansion of $p 53^{\text {null }}$ blasts retaining Runx1. Surprisingly, Runx1 could be excised completely from established EpMyc lymphoma cell lines in vitro without obvious effects on cell phenotype. Established lines lacked functional p53, and were sensitive to death induced by introduction of a temperature-sensitive p53 (Val135) allele. Transcriptome analysis of Runx1-deleted cells revealed a gene signature associated with lymphoid proliferation, survival and differentiation, and included strong de-repression of recombination-activating (Rag) genes, an observation that was mirrored in a panel of human acute leukemias where RUNX1 and RAG1,2 mRNA expression were negatively correlated. Notably, despite their continued growth and tumorigenic potential, Runxi ${ }^{\text {null }}$ lymphoma cells displayed impaired proliferation and markedly increased sensitivity to DNA damage and dexamethasone-induced apoptosis, validating Runx1 function as a potential therapeutic target in Myc-driven lymphomas regardless of their p53 status.

\section{INTRODUCTION}

Runx 1 encodes a transcription factor that plays a vital role in development of the haematopoietic system [1]. It belongs to a three-membered family of mammalian gene products that bind a common DNA target sequence by virtue of the conserved Runt domain and share a common heterodimeric binding co-factor, $\operatorname{CBF} \beta[2,3]$. Like their Drosophila homologue, Runt, the Runx proteins function as transcriptional regulators and are capable of activating or repressing target promoters through the recruitment of co-activators or co-repressors [4]. The RUNX1 (AML1) and CBFB genes are among the most commonly involved in human leukemias where they are affected by chromosomal translocations that frequently generate fusion oncoproteins [5].

Evidence that simple over-expression of any of the Runx gene family members can drive oncogenesis emerged first from mouse models, where it was shown that all three genes can act as targets for murine leukemia virus (MLV) insertional mutagenesis and transcriptional activation in lymphoma. Common targets in the E $\mu$-Myc lymphoma model include Runx1 and Runx3 [6], while all three members of the Runx family were identified as activation targets in CD2-MYC T-cell lymphomas [79]. The potent oncogenic effect of combining Myc and Runx over-expression is emphasised further in retroviral acceleration of lymphoma onset in Runx 2 transgenic mice 
which frequently entails activation of $\mathrm{c}-M y c$ or N-Myc [10], while compound transgenic mice over-expressing Myc and Runx genes in the T or B-cell compartment display very rapid tumor onset [10-12]. However, the Runx family are not merely cofactors for Myc oncogenesis; CD2-Runx2 transgenic mice display dose-dependent predisposition to lymphoma [11, 13] and strongly synergistic lymphoma development in combination with other oncogenes such as Pim- 1 and $v-M y b$, as well as with loss of p53 [10]. Notably, the combination of Runx2 and $M y c$ oncogenes appears to overcome the need for mutational inactivation of p53 [14] despite the fact that both genes can trigger the p53 pathway and collaborate with p53 loss when over-expressed individually $[15,16]$.

In contrast to this catalogue of evidence of dominant oncogenic activity in lymphomagenesis, Runxl deficient cells in chimeric mice develop T-cell lymphomas after treatment with ENU [17], suggesting that loss of Runx I activity can also predispose to lymphoid malignancy. A similar dichotomy of observations exists for RUNX1 in human haematopoietic cancers. $R U N X 1$ is among the most over-expressed genes in childhood ALL [18] and is highly amplified in a poor prognostic B-ALL subgroup [19] while presumptive loss-of-function $R U N X 1$ mutations have been observed in a small proportion of T-ALLs where network analysis further implicated $R U N X 1$ as a candidate tumor suppressor [20]. More extensive evidence of a tumor suppressor role for RUNX1 has come from myeloid malignancies where loss of function mutation is frequently observed in AML, and underlies familial platelet disorder with predisposition to AML [21, 22].

While the lymphomagenic effects of Runx overexpression have been amply demonstrated, the requirement for basal gene expression in tumor maintenance is an important and potentially far-reaching question that has been much less well investigated. In this study we tested the effects of ablating the endogenous Runxl gene in the well-characterised E $\mu$-Myc lymphoma model system [23] where ectopic expression of Runxl is known to drive lymphomagenesis [12]. We show that primary E $\mu$-Myc lymphomas have an increased requirement for Runxl, while this dependency is reduced, but not eliminated, in end-stage p53-deficient lymphoma cell lines. Our findings shed light on the paradoxical observation that Runxl deficiency can also predispose to lymphoma but more importantly validate Runx 1 function as a therapeutic target in p53 wild-type or mutant lymphomas.

\section{RESULTS}

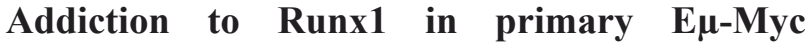 lymphoma cells is attenuated in established cell lines}

E $\mu$-Myc mice develop lymphomas with highly variable onset (average 30 weeks) during which they acquire a range of secondary mutations in the Cdkn2a-p53 pathway [24]. To achieve more homogeneous tumor onset and facilitate tracking of p53 loss along with Runxl deletion, we crossed these mice to a $\operatorname{Tr} p 53^{+/}$background. $\mathrm{E} \mu-\mathrm{Myc} / \mathrm{p} 53^{+/}$mice succumb to B-cell lymphomas within a much narrower time window [25]. These mice were further crossed to generate Mx1Cre/Runx $I^{f / f l}$ cohorts in which we could examine the ability of lymphoma cells to survive deletion of the endogenous Runxl gene.

Surprisingly, we found no significant difference in the rate of onset of lymphoma in $\mathrm{E} \mu-\mathrm{Myc} / \mathrm{p} 53^{+/-}$ Runx $1^{f / f}$ mice with active Cre recombinase (Figure 1A, 1B), initially suggesting that Runx 1 loss had no effect on tumor onset. However, PCR analysis (Figure 1C) of tumor-bearing spleens showed that the intact Runxl allele was strongly retained in the primary tumors, even in $\mathrm{pIpC}$-treated mice. Spleens from mice with end-stage disease, which were markedly enlarged due to lymphoma expansion, showed levels of Runxl deletion significantly lower than normal splenic lymphoid cells from age-

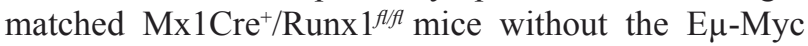
oncogene, indicating an increased rather than a decreased requirement for Runxl in primary lymphoma cells (Figure $1 \mathrm{C}$, upper panel and lower right panel).

While the cell lines derived from these lymphomas almost uniformly retained the functional active Runxl allele on initial establishment in culture (Figure 1D, upper left panel), they were able to survive excision of both wildtype alleles after treatment with IFN $\beta$ in vitro (Figure 1D, upper right panel). Moreover, single cell cloning of these lines after low dose IFN $\beta$ readily generated subclones with 0,1 or 2 intact Runxl alleles (Figure 1D, lower panel). Using these lines we validated the direct PCR assay as a consistent measure of the proportion of excised to non-excised allele. In this assay, the observed ratio of excised to non-excised allele is proportionate to input and independent of DNA concentration (Figure S1A, S1B).

\section{Permissiveness for Runx1 deletion is lineage- dependent}

In accord with previous reports [26], analysis of non-tumor bearing mice revealed lineage-dependence in permissiveness for Runxl deletion. Healthy tissues showed a marked difference in the levels of spontaneous and enforced deletion of Runxl, with thymus consistently 
more resistant than kidney or spleen. However, even the permissive tissues showed at most 50\% deletion (Figure 2A). Mono-allelic deletion in Runx $1^{\text {flft }}$ cells has been reported previously in Runx1-dependent tissues from vav-CreRunx $1^{\text {flff }}$ mice [26]. These results suggest that a strong homeostatic process selects for cells that retain at least one copy of Runx1. Consistent with this hypothesis, the cell type composition of spleen showed remarkably little change after enforced Runx 1 deletion (Figure 2B). However, fractionation of spleen cells into lymphoid $\left(\mathrm{B}_{22}{ }^{+}\right.$or $\left.\mathrm{CD}^{+}\right)$or myeloid $\left(\mathrm{Macl}^{+}\right)$confirmed the relative permissiveness of the myeloid compared to the lymphoid compartment for deletion of Runx1 [26] (Figure 2C).

A

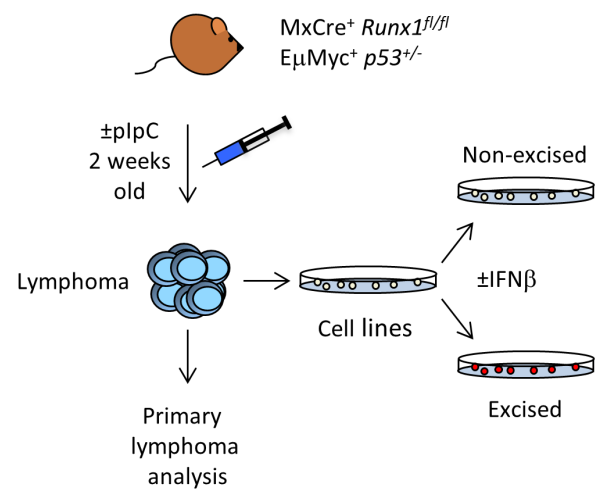

B

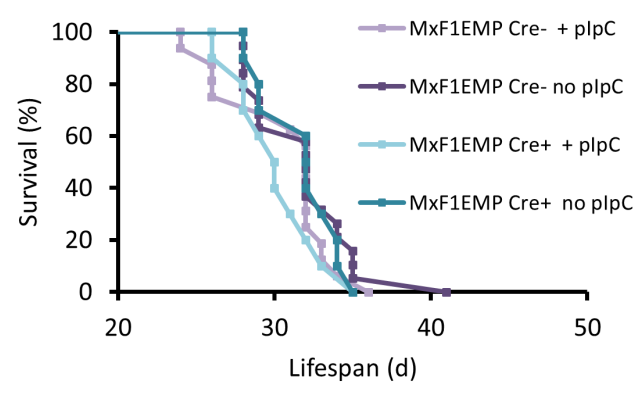

Enforced deletion of Runx1 promotes the outgrowth of p53 null cells in E $\mu-\mathrm{Myc} / \mathrm{p53+/-}$ lymphomas

Established lymphoma cell lines were found to have lost the wild-type Trp53 allele in most cases and displayed consistent de-repression of $\mathrm{Cdkn} 2 \mathrm{a} / \mathrm{p} 19^{\text {Arf }}$ [24] (Figure 3A, S2A). We therefore considered whether the contrasting behaviour of primary lymphomas and established cell lines with regard to retention of Runx 1 was a consequence of loss of the wild-type Trp53 allele. To address this hypothesis further and examine the temporal order of events in vivo, we analysed the minor

C
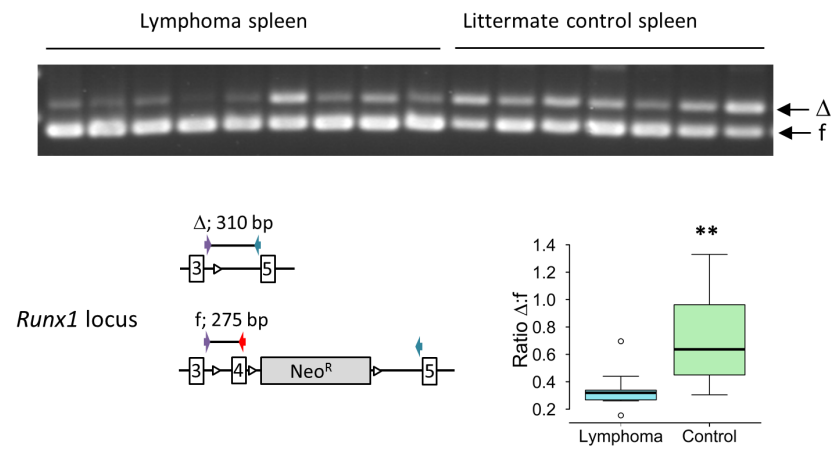

$\mathrm{D}$
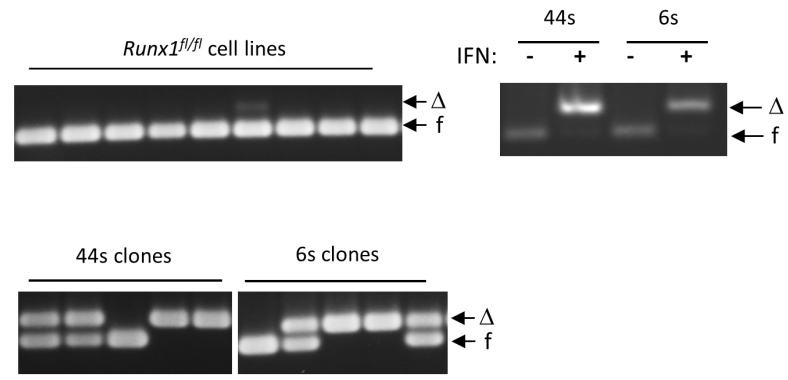

Figure 1 : E $\mu$-Myc lymphomas strongly resist deletion of Runx1 in vivo but not in vitro. A. Outline experimental design Lymphomas derived from $\mathrm{Mx} 1 \mathrm{Cre}^{+} / R u n x l^{A / f / f} / \mathrm{E} \mu-\mathrm{Myc} / p 53^{+/}$mice were analysed and also used to establish cell lines that could be treated

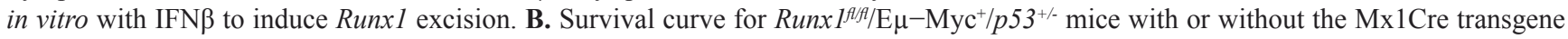
and with or without pIpC treatment to excise Runxl. Statistical analysis by Wilcoxon Rank Sum test showed no significant difference in survival between the groups of mice. C. Upper panel : Runxl excision PCR on genomic DNA derived from lymphoma spleen tissue of

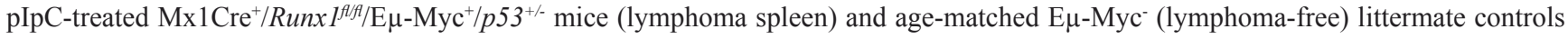
(littermate control spleen). Arrows indicate Runxl-floxed (f) and Runxl-deleted ( $\Delta$ ) bands. The panel below left shows a diagram of the multiplex PCR for detection of deleted $(\Delta)$ and floxed (f) Runx1. The cartoon shows loxP sites flanking exon 4 in the floxed allele before and after excision, location of primers (colored arrows) and size of PCR products. The panel below right shows the ratio of excised:nonexcised band intensity determined by densitometry for the Runxl excision PCR samples shown in 1C. Boxplot shows the distribution of all the $\Delta$ :f ratios with the box representing the $1^{\text {st }}$ to $3^{\text {rd }}$ quantiles (Q1 to Q3) and the midline representing the median. Whiskers represent the smaller of the most extreme data point, or 1.5x the Q1-Q3 interquantile range. Asterisks denote statistical significance, with $p=0.008 \mathrm{D}$. The upper left panel shows Runxl excision PCR on genomic DNA from a series of independent cell lines derived from $\mathrm{Mx} 1 \mathrm{Cre}+/ \mathrm{Run} \mathrm{l}^{\mathrm{Al} / \mathrm{f} /}$ $\mathrm{E} \mu-\mathrm{Myc}^{+} / p 53^{+/}$lymphomas. The right panel shows Runxl excision PCR on genomic DNA from samples of $44 \mathrm{~s}$ and $6 \mathrm{~s} \mathrm{Mx1Cre} /$ Runx $1^{f / t} /$ $\mathrm{E} \mu-\mathrm{Myc}^{+} / p 53^{+/}$cell lines treated with IFN $\beta$ to excise Runx 1 or with vehicle control; cell samples were taken 2 days after the start of IFN $\beta$ treatment. The lower panel shows Runxl excision PCR on genomic DNA from single cell clones derived from the 44s and $6 \mathrm{~s}$ Mx1Cre ${ }^{+} /$ $R u n x 1^{f f f} / \mathrm{E} \mu-\mathrm{Myc}^{+} / p 53^{+/}$cell lines; cells were treated with a sub-optimal dose of IFN $\beta$ to induce partial excision of Runxl and single cell cloned as detailed in Materials and Methods. Arrows indicate Runxlfloxed (f) and Runxl-deleted ( $\Delta$ ) bands. 
blastic fraction of cells from end-stage lymphoma-bearing spleens, a procedure that has been shown to enrich for the most rapidly proliferating cells within the tumor [27]. The fractionated blasts displayed strong enrichment for cells that had lost the wild-type Trp53 allele (Figure $3 \mathrm{~B})$. The fact that most lymphoma blast cells retained at least one Runx 1 allele indicated that loss of p53 was an earlier event that preceded permissiveness for Runx 1 loss, a conclusion reinforced by findings on newly established cell lines (Figure 1D, upper left panel). Enrichment for p53-deleted blasts was observed most strongly in pIpC- treated mice, suggesting that attempts to enforce deletion of Runx 1 may have perturbed the tissue sufficiently to create a permissive niche for outgrowth of bystander p53 /- blasts. These results further emphasise the importance of Runx 1 for survival of E $\mu$-Myc lymphoma cells in vivo, even though it becomes dispensable in established cell lines in vitro.

The hypothesis that Runx 1 is required to counteract the growth suppressive effects of p53 was tested by transduction of a p53 null E $\mu-M y c / R u n x 1^{\text {flfl }}$ lymphoma cell line (3s) with a temperature-sensitive p53 allele

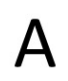

plpC-treated

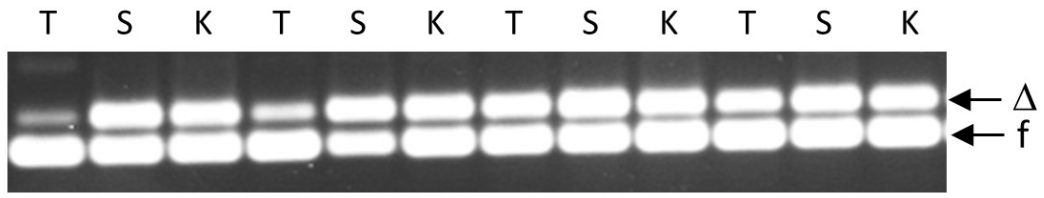

control

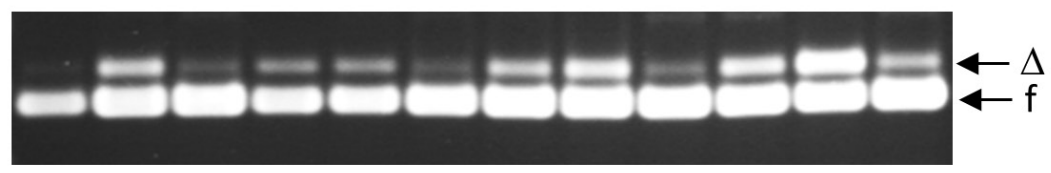

B

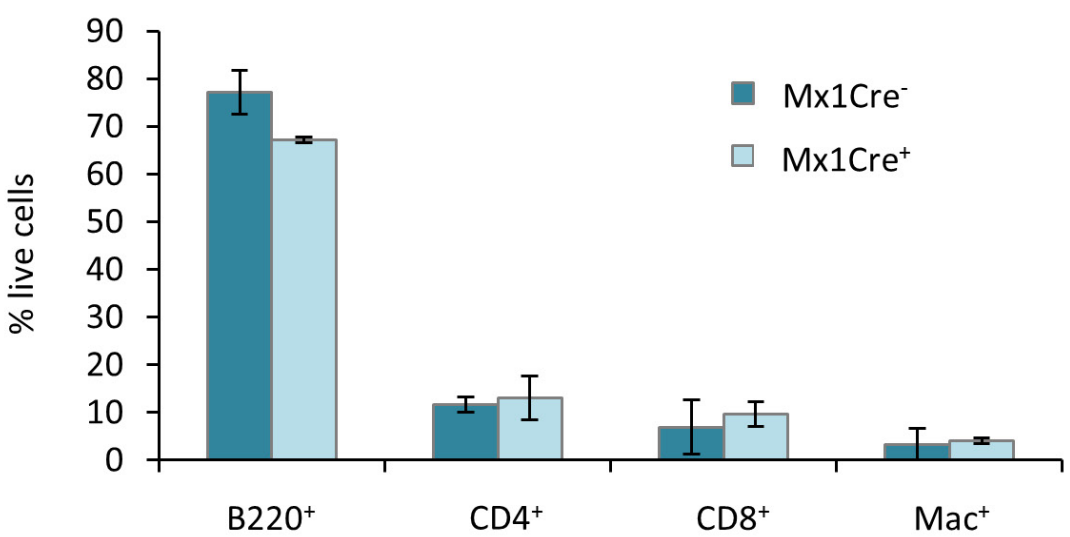

C
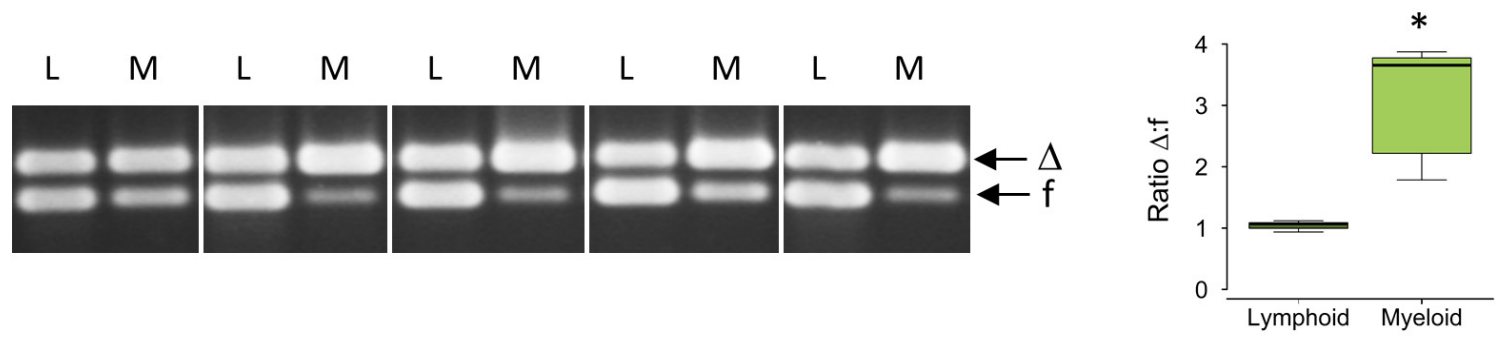

Figure 2: Healthy tissues display lineage-specific differences in permissiveness for $\boldsymbol{R} u n \boldsymbol{x} 1$ deletion. A. Runx 1 excision PCR analysis of genomic DNA from whole thymus (T), spleen $(\mathrm{S})$ and kidney $(\mathrm{K})$ of non-lymphoma-bearing adult $R u n x l^{f / f}$ mice treated (upper panel) or untreated (lower panel) with pIpC to induce Mx1Cre expression. Arrows indicate Runxlfloxed (f) and Runxl-deleted ( $\Delta$ ) bands. B. Flow cytometric analysis of spleen cell populations in pIpC-treated Mx1Cre- and Mx1Cre ${ }^{+}$E $\mu-M y c-$ healthy littermate control mice. Plot shows mean \pm SD for measurements from 3 mice in each group; no statistically significant differences between the Mx $1 C \mathrm{Cr}^{+}$and Mx1Cre- cell populations were found. C. Runx1 excision PCR analysis of genomic DNA from sorted lymphoid (B220 ${ }^{+}$or CD3 ${ }^{+}$cells; L) and myeloid $\left(\mathrm{Mac1}^{+} ; \mathrm{M}\right)$ cells from non-lymphoma-bearing spleens of $5 \mathrm{pIpC}$-treated adult Runx $1^{\text {flf }}$ mice. Boxplot shows the distribution of all the $\Delta:$ f ratios as described in Figure 1. Asterisk indicates that the difference is statistically significant $(p=0.01)$. 
(Val135). After transduction, interferon treatment was used to produce matched pairs of cell lines with or without endogenous Runx1 that could be tested for sensitivity to p53-induced death. However, the p53 "add-back" cells died by apoptosis at the permissive temperature $\left(32^{\circ} \mathrm{C}\right)$ regardless of their Runx1 status or exposure to UV irradiation (Figure 3C, 3D, S2B). The functional integrity of the p53 pathway was maintained with respect to downregulation of $\mathrm{Cdkn} 2 \mathrm{a} / \mathrm{p} 19^{\mathrm{ARF}}$ in response to temperature shift but the major target for p53-mediated growth arrest, $\mathrm{Cdkn} 1 \mathrm{a} / \mathrm{p} 21^{\mathrm{WAF} 1}$, was undetectable in these cells (Figure $3 \mathrm{E}$ ), suggesting a partial functional deficit. As it has been reported that p53 can affect Runx 1 expression in T-cells [28], we also examined Runx 1 expression in $3 \mathrm{~s}$ cells, but saw no evidence of modulation by p53 (Figure 3E).

\section{Runx1 deficient cells display down-regulation of genes involved in growth and proliferation along with de-repression of Rag genes}

Changes in gene expression resulting from deletion of Runxl were examined using Affymetrix gene expression microarrays (Affymetrix GeneChip MTA 1.0). Three biological replicates of the $3 \mathrm{~s}$ cell line were compared. Possible confounding effects of IFN $\beta$ treatment and Cre recombinase induction were controlled by comparison with a phenotypically matched E $\mu-\mathrm{Myc}$ lymphoma cell line (30s) of the same genotype apart from the non-deletable Runx $1^{\text {wt } / w t}$ allele. Treatment with IFN $\beta$ had no effect on Runx1 expression in these cells (Figure S3A, S3B).

Many genes showed changes in expression specific
A

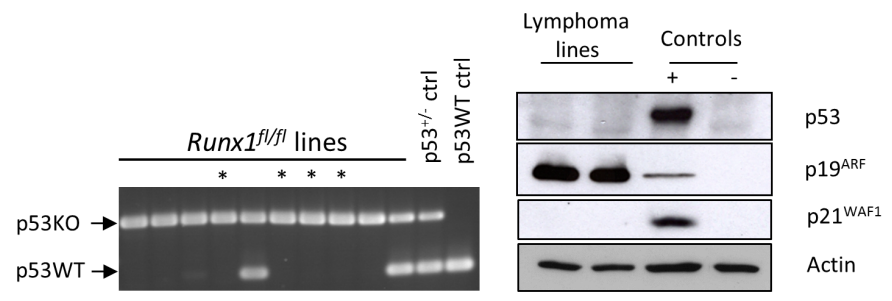

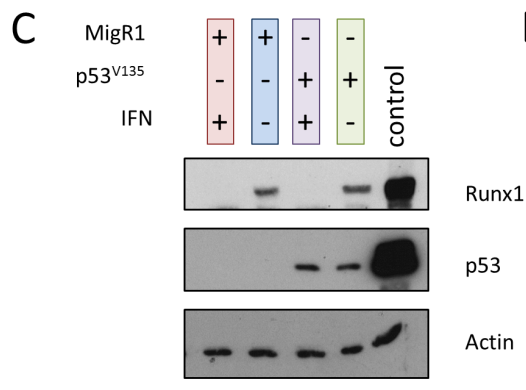

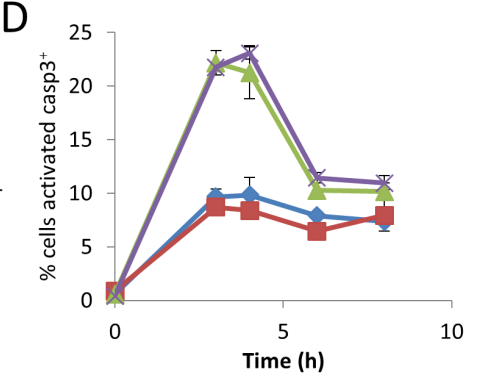

B

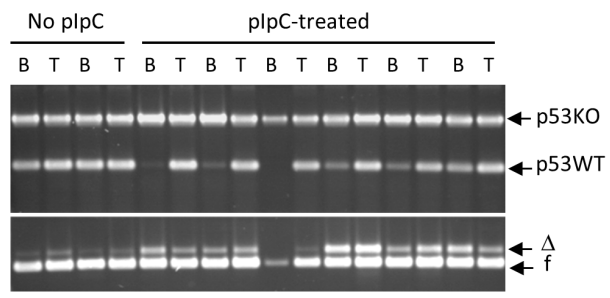

$\mathrm{E}$

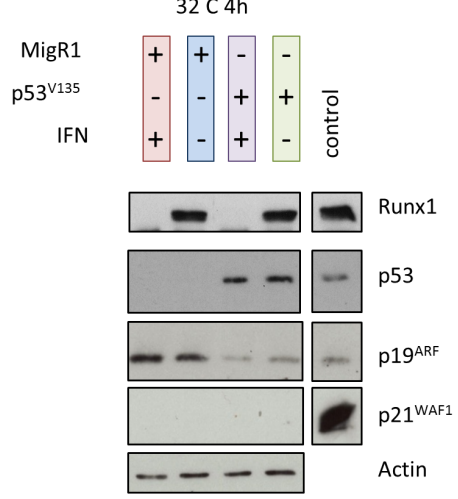

Figure 3: Loss of p53 precedes permissiveness for Runx1 deletion during establishment of lymphoma cell lines. A. Left panel: p53 allele PCR on genomic DNA from a series of independent cell lines derived from lymphomas in $\mathrm{Mx} 1 \mathrm{Cre} / R u n x 1^{f / f} / \mathrm{E}^{+}-\mathrm{Myc} \mathrm{c}^{+} /$ $p 53^{+/}$mice; arrows indicate $\mathrm{p} 53^{\text {null }}$ (p53KO) and wild type (p53WT) alleles in control samples for $\mathrm{p} 53^{\mathrm{wt} / \mathrm{wt}}$ and $\mathrm{p} 53^{+/}$; asterisks indicate cell lines established from $\mathrm{pIpC}$-treated mice. Right panel: western blot analysis of total protein extracted from two established and independent lymphoma cell lines derived from lymphomas in $\mathrm{Mx} 1 \mathrm{Cre}^{+} /$Runx $1^{f / f /} / \mathrm{E} \mu-\mathrm{Myc}^{+} / p 53^{+/}$mice that did not receive pIpC treatment. Extracts were probed with antibodies to $\mathrm{p} 53, \mathrm{p} 19^{\mathrm{ARF}}$ and $\mathrm{p} 21^{\mathrm{WAF} 1}$. Actin was used as a loading control. Positive controls are listed in Materials \& Methods and used in all subsequent analyses. B. Upper panel shows p53 allele PCR on genomic DNA from sorted blast cells (B) or whole tissue (T) from lymphoma-bearing spleens of untreated and $\mathrm{pIpC}$-treated $\mathrm{Mx} 1 \mathrm{Cre}{ }^{+} / R u n x 1^{f / f} / \mathrm{E} \mu-\mathrm{Myc}^{+} / p 53^{+/}$mice, while the lower panel shows Runxl excision PCR on the same DNA samples. Blast cells were sorted using CD45/SSC on B220 cells as detailed in Materials and Methods. Arrows indicate p53 ${ }^{\text {null }}$ (p53KO) and wild type (p53WT) alleles, and Runxlfloxed (f) and Runxl-deleted ( $\Delta$ ) bands. C. Cells transduced with vector expressing temperature-sensitive $\mathrm{p} 53^{\mathrm{V} 135}$ or the MigR1 control vector were treated with IFN $\beta$ to excise endogenous Runx1, and expression of $\mathrm{p} 53$ and Runx 1 examined by western blot analysis. D. Paired Runx $1^{+}$and Runx $1^{\text {null }} \mathrm{p} 53$ addback cell lines treated with $5 \mathrm{~J} / \mathrm{m}^{2} \mathrm{UV}$ were grown at $32^{\circ} \mathrm{C}$ to activate temperature sensitive p53 and stained for intracellular activated caspase 3 after $3,4,6$ and $8 \mathrm{~h}$ incubation. The percentage of cells expressing activated caspase 3 was determined by flow cytometry. Line colors are indicated by the color-coding of the western blots samples in 3C. E. Western blot analysis of total protein extracted from the experiment as shown in (D) $4 \mathrm{~h}$ after UV treatment. Extracts were probed as before and loading confirmed by actin expression. 
A

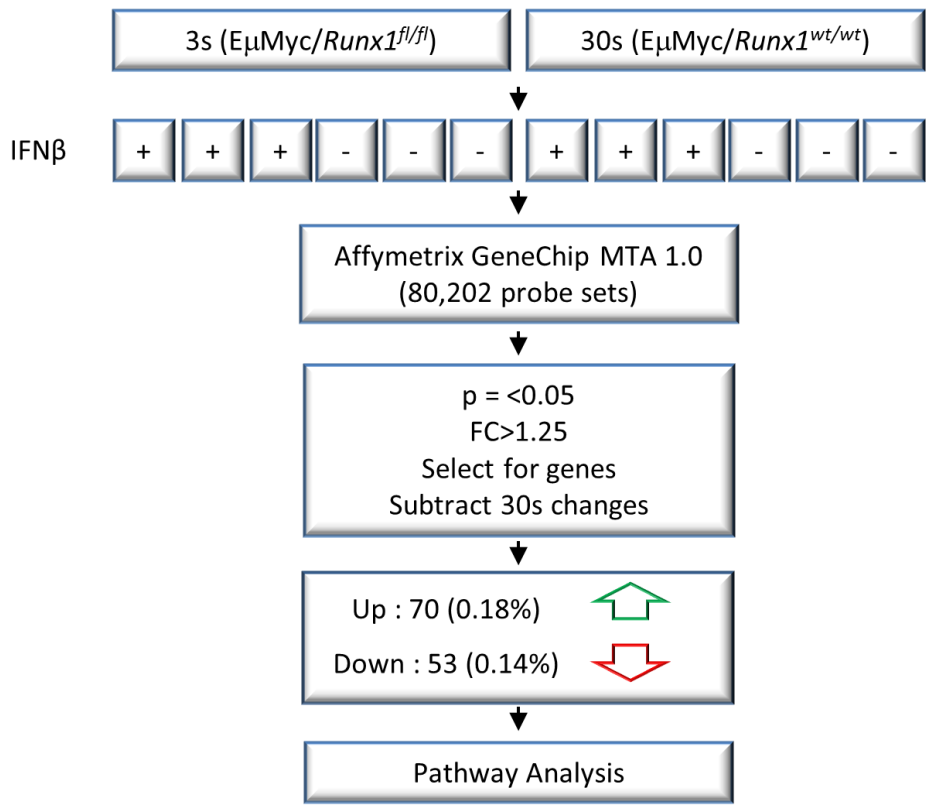

B

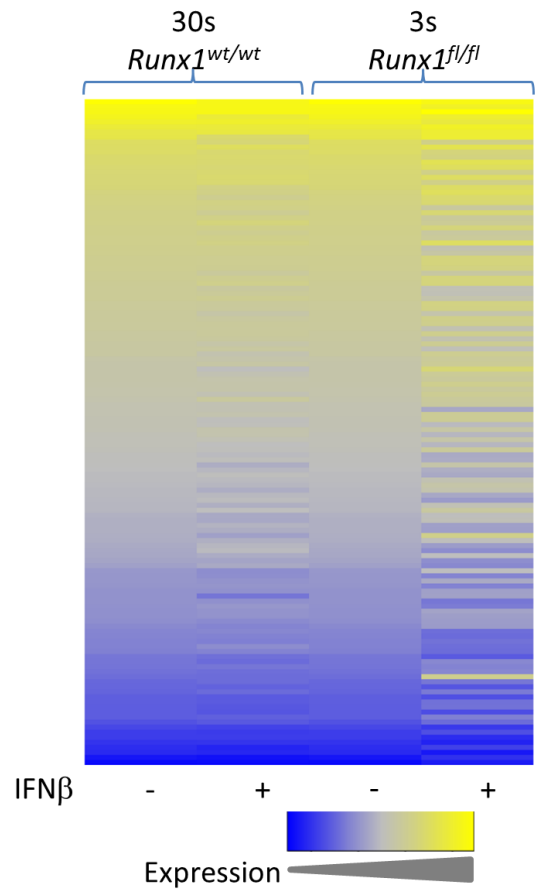

Figure 4: Gene expression microarray analysis of E $\mu$-Myc lymphoma cells before and after Runx1 excision A. Process overview. 3s+ and 30s+ cell lines derived from Mx1Cre $/$ Runx $l^{\mu f f /} / \mathrm{E} \mu-\mathrm{Myc}^{+} / p 53^{+/}$mice were treated with IFN $\beta$, excising Runx1 from

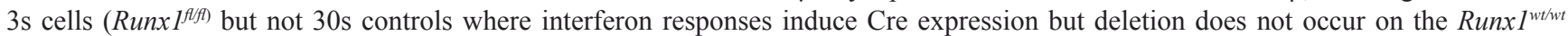
background (see also Figure S3). RNA was extracted and gene expression examined by Affymetrix microarray. Significantly changed genes were selected by $p$-value and fold-change and a subset that were also significantly changed in 30 s cells were subtracted to exclude non-Runx1 related changes. This gene list was then used in downstream analyses such as pathway analysis. B. Heat map of all genes significantly changed in $3 \mathrm{~s}$ cells, defined as $p<0.05$ and fold change $>|1.25|$. Shown is raw intensity for $3 \mathrm{~s}$ and $30 \mathrm{~s}$ cells. Low expression is shown in blue and high expression in yellow. 30s gene expression was normalised to $3 \mathrm{~s}$ control (-IFN $\beta$ ) expression.

A

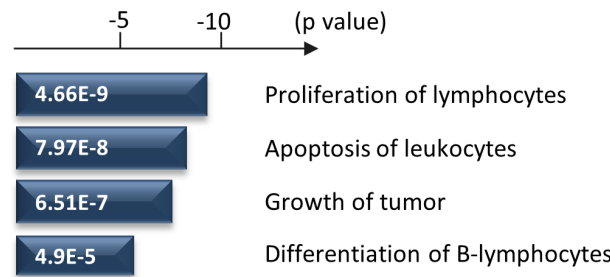

C

\begin{tabular}{lccc}
\hline \multicolumn{1}{c}{ mRNA } & 30s Array & 3s Array & 3s RQ-PCR \\
\hline Bcl11a & -1.01 & 1.42 & 4.72 \\
\hline Cd55 & 1.01 & 1.42 & 4.14 \\
\hline Daf2 & -1.07 & 1.28 & 4.02 \\
\hline II7r & 1.02 & 1.29 & 1.22 \\
\hline Ptpn22 & -1.03 & 1.32 & 7.09 \\
\hline Prkcb & 1.12 & 1.49 & 2.93 \\
\hline Nckap1 & -1.01 & -7.97 & -12.93 \\
\hline Rag1 & -1.09 & -1.41 & -6.31 \\
\hline Rag2 & -1.20 & -2.99 & -4.15
\end{tabular}

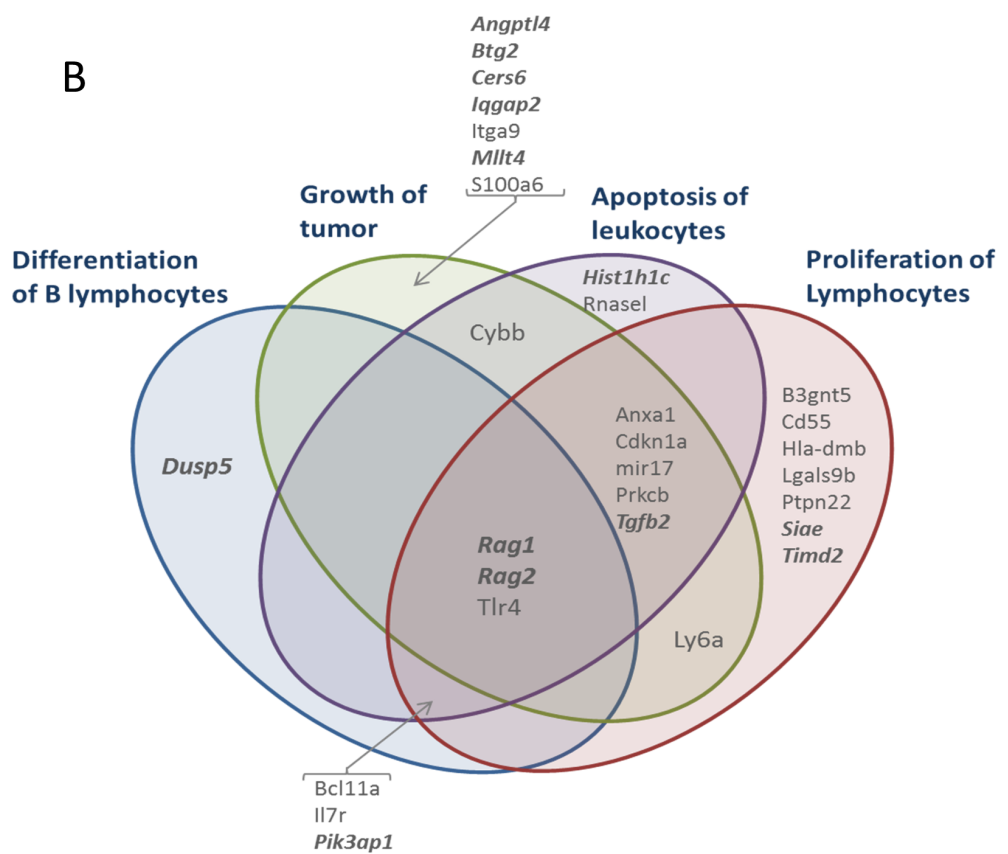

Figure 5: Gene expression changes specific for Runx1 deletion in E $\mu$-Myc lymphoma cells. A. Ingenuity Pathway Analysis of the most changed genes (Figure 4) revealed significant enrichment for genes involved in the processes depicted. $P$-values are shown for top sub-processes in relevant categories. B. Venn diagram showing the overlap of the gene signatures for the significant processes in A. Genes in bold italics show increased expression on loss of Runxl, while the remainder are down-regulated. C. Validation of key target genes contributing to the Runx1 deletion signatures. Fold changes estimated by microarray and RQ-PCR are shown alongside comparable array values for the 30 s control cells. 
to the Runx $1^{\text {flff }}$ genotype. To focus on the most prominent changes we applied a statistical significance threshold of $p=<0.05$ and a fold change cut-off of 1.25. After subtraction of genes significantly changed in the $30 \mathrm{~s}$ control, this left 123 genes of which 70 were up-regulated and 53 down-regulated on excision of Runxl (Figure 4A). As can be seen from the heat map in Figure 4B, the control 30s cells showed relatively modest changes after IFN $\beta$ treatment compared to Runx $1^{\text {fl/ }} 3 \mathrm{~s}$ cells. The gene set specific for Runx1 loss was subjected to Ingenuity Pathway Analysis which revealed significant associations with cancer and in particular with proliferation, apoptosis and differentiation of lymphocytes (Figure 5A). The direction of changes on deletion indicated that Runx 1 is acting to sustain proliferation and survival while impeding differentiation in these cells (Figure 5B). Ragl and Rag2 were common components of all four pathway clusters (Figure 5B) and were among the most strongly de-repressed genes in Runx1-deleted cells. Validation of the changes in Rag genes and other signature genes by quantitative real-time PCR confirmed the array findings and revealed larger fold changes in most cases, consistent with the precision but systematic underestimation of differences by this methodology [29] (Figure 5C).

As recent studies have defined Runx1/RUNX1 gene expression signatures in other contexts, we examined our array data for similar changes in the key genes. An RNASeq study of normal haematopoietic stem and progenitor cells using the same Runx $1^{\text {flff }}$ allele revealed a ribosome biogenesis gene expression signature associated with loss of Runx1 [30]. However, we saw no significant difference in these genes. A subset of the most changed genes from the signature gene set is shown in Figure S3C. Nor did we note any obvious change in cell size or morphology in

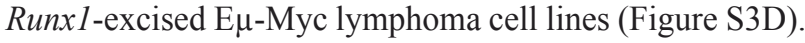
We also examined a mitotic checkpoint gene signature that was reported in Kasumi/AML cells after knockdown of RUNX1 [31]. The genes shown in Figure S3E were all significantly downregulated in Kasumi knockdown cells but were mostly unchanged in Runx $1^{\text {null }} \mathrm{E} \mu$-Myc lymphoma cells. Only Nek6 was significantly downregulated while two of the genes showed a significant increase (Nek2, Bub1b).
A

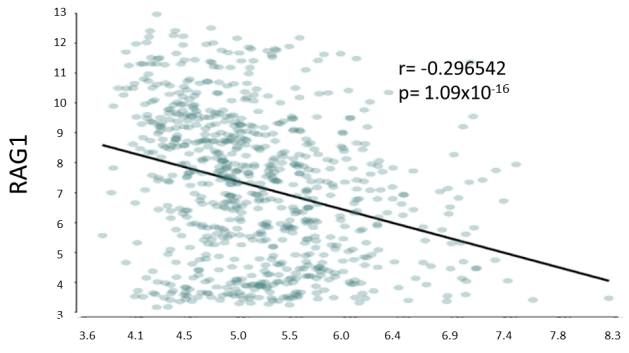

B

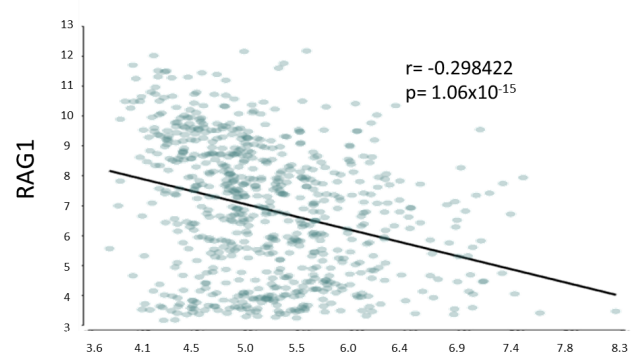

C

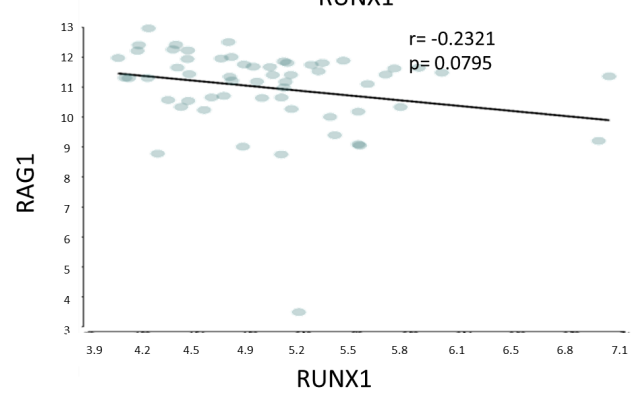

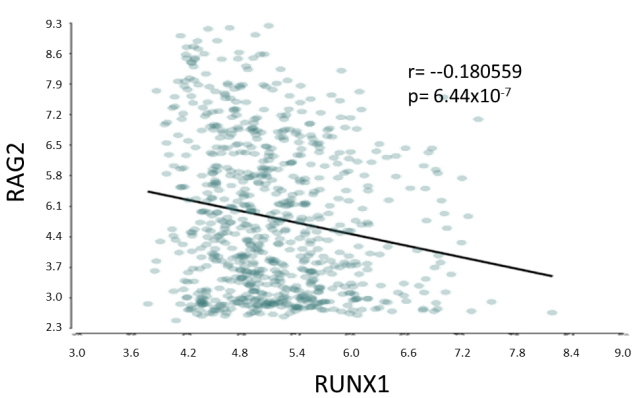

all ALL subtypes
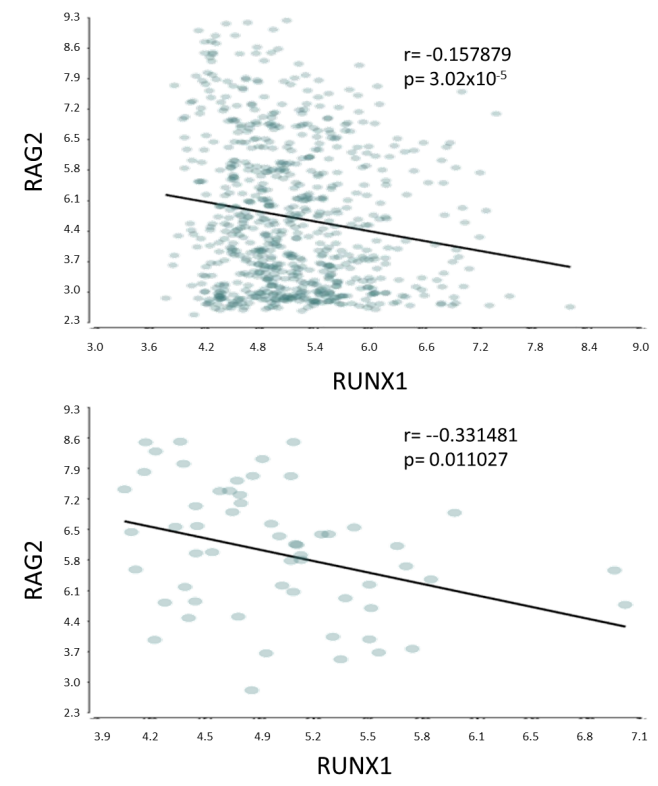

all ALL subtypes

excluding $t(12 ; 21)$

all ALl subtypes

(12;21)

$t(12 ; 21)$ only

Figure 6: $R U N X 1$ mRNA expression is negatively correlated with $R A G 1$ and $R A G 2$ in a large panel of human ALLs. Pearson correlation plots of gene expression (probeset intensities) of RUNX1 vs RAG1 or RAG2 in A all ALL subtypes within the MILE database (ref [33]) $(n=750)$, B. all ALL subtypes with the exception of the $\mathrm{t}(12 ; 21) / E T V 6-R U N X 1$ subset $(n=692)$, C. the $\mathrm{t}(12 ; 21)$ translocation only $(n=58)$. Plots show $p$-value and r-value. 


\section{Negative correlation of RUNX1 and RAG mRNA expression in a human leukemia panel}

Aberrant RAG activity has recently been reported as a major source of cancer driver mutations in TEL-RUNX1 $\mathrm{t}(12 ; 21)$ B-cell leukemias [32], leading us to consider whether there may be a wider role for RUNX1 in RAG mis-regulation in human leukemia/lymphomas. Using Partek Genomics Suite 6.6 we examined the relationship between expression of RUNX1 and RAG1/RAG2 expression in a panel of acute and chronic leukemias from the MILE study (Microarray Innovations in LEukemia), a global microarray study comprising gene expression

A

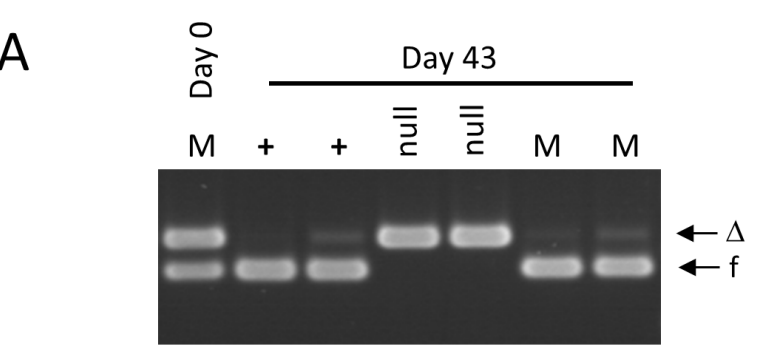

C

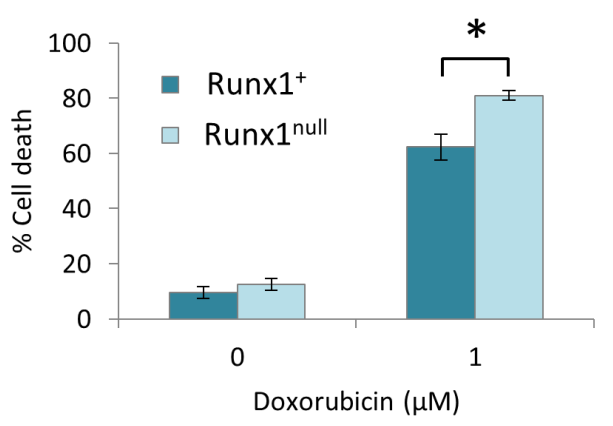

analysis of $>4000$ patients [33]. As shown in Figure S4, RUNX1 mRNA expression was relatively uniform compared to the $R A G$ genes that displayed markedly higher expression in ALLs compared to normal tissues and myeloid leukemias. Also, expression of RAG1 was significantly higher in $\mathrm{t}(12 ; 21)$ ALLs than in other ALL types (Figure S4). Comparison of the levels of RUNX1 and the $R A G$ genes within the dataset $(n=750)$ identified significant, negative correlations between $R U N X 1 / R A G 1$ and $R U N X 1 / R A G 2$ (Figure 6). This pattern was evident in the total ALL dataset with or without the $\mathrm{t}(12 ; 21)$ subset, where interpretation is more complex due to the detection of TEL-RUNX1 as well as RUNX1 mRNAs by the RUNX1

B
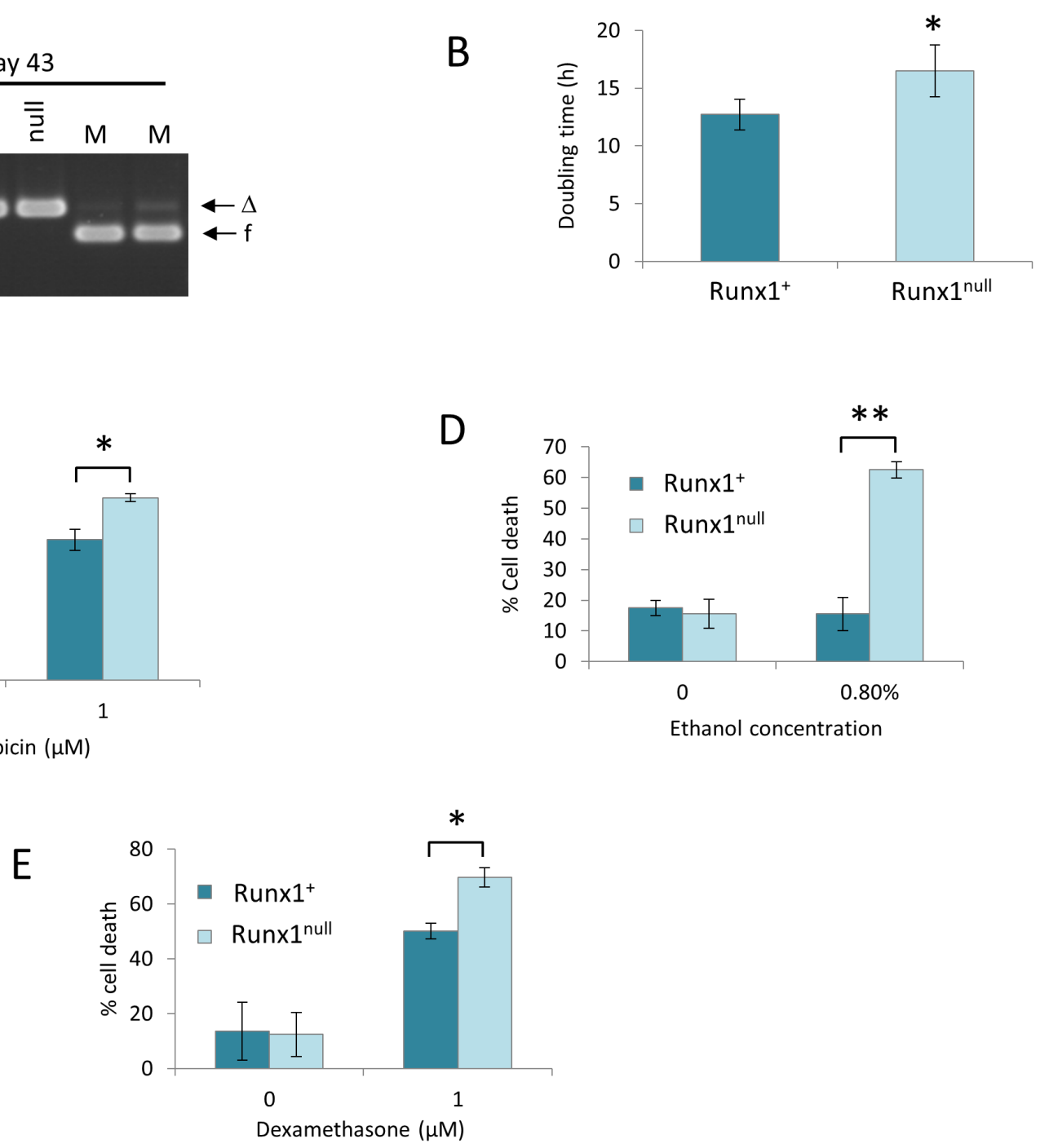

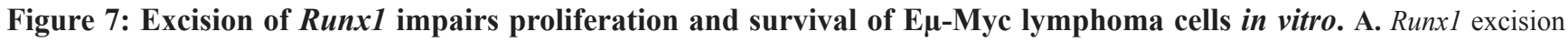
PCR analysis of genomic DNA from duplicate samples of $R u n x I^{+}(+)$and Runx $I^{\text {null }}$ (null) cells or of a 1:1 mixture of these cells (M) on day 0 and after culture for 43 days. Arrows indicate Runxl floxed (f) and Runxl-deleted ( $\Delta$ ) bands. Results shown are from a single experiment representative of 3 independent experiments. B. Increased doubling time of Runx $I^{\text {null }}$ cells. Runx $I^{+}$and Runx $I^{\text {null }}$ cells were plated at a density of $2 \times 10^{5}$ cells $/ \mathrm{ml}$ and cultured for $24 \mathrm{~h}$ before counting. Doubling time was calculated as described in Materials and Methods. C.-E. Increased sensitivity of Runx $1^{\text {null }}$ cells to chemotherapeutic agents and oxidative stress. Runx $1^{+}$and Runx $1^{\text {null }}$ were plated at $2 \times 10^{5}$ cells $/ \mathrm{ml}$ and treated with $1.0 \mu \mathrm{M}$ doxorubicin (C), $0.8 \%$ ethanol (D) or $1.0 \mu \mathrm{M}$ dexamethasone (E) for $24-30$ hours before viability counting. Plots show mean $\pm \mathrm{SD}$ for a single experiment carried out in triplicate and are representative of at least 3 independent experiments; $*=p<0.05$, $* *=p<0.01$. 
probe sets. While the lack of significant correlation between RUNX1 and RAG1 and the weaker correlation between $R U N X 1$ and $R A G 2$ in $\mathrm{t}(12 ; 21)$ cells is therefore difficult to interpret, the strongly negative correlation in other ALL sets is a robust observation.

\section{E $\mu-M y c$ lymphoma cells lacking Runxl display growth impairment and increased sensitivity to genotoxic stress and dexamethasone-induced apoptosis}

Careful observation suggested that the Runx $1^{\text {null }}$ cell lines grew more slowly, and this suspicion was confirmed by serial passage of clonal E $\mu-\mathrm{Myc} /$ Runx $^{\text {fl/f }}$ cell lines in which partial excision had been induced. Cells retaining Runx 1 consistently outgrew their null clonal siblings (Figure 7A). This disadvantage could be accounted for by the observed lengthening of doubling time in Runx 1deleted cells (Figure 7B) operating over the prolonged culture period. Marked differences were also noted when cells were exposed to genotoxic stresses, where Runx $1^{\text {null }}$ cells displayed more rapid death in the presence of doxorubicin or ethanol (Figure 7C, 7D). The effects of ethanol were particularly potent on Runx $1^{\text {null }}$ cells (Figure 7D), possibility reflecting the fact that ethanol elicits wider oxidative stress-induced effects in addition to DNA damage $[34,35]$. In light of our previous findings that ectopic Runx1 expression suppresses glucocorticoid growth inhibition in murine fibroblasts [36] we also tested the effects of dexamethasone. Again, Runx1-deficient E $\mu$-Myc lymphoma cells displayed significantly greater induction of cell death (Figure 7E)

A

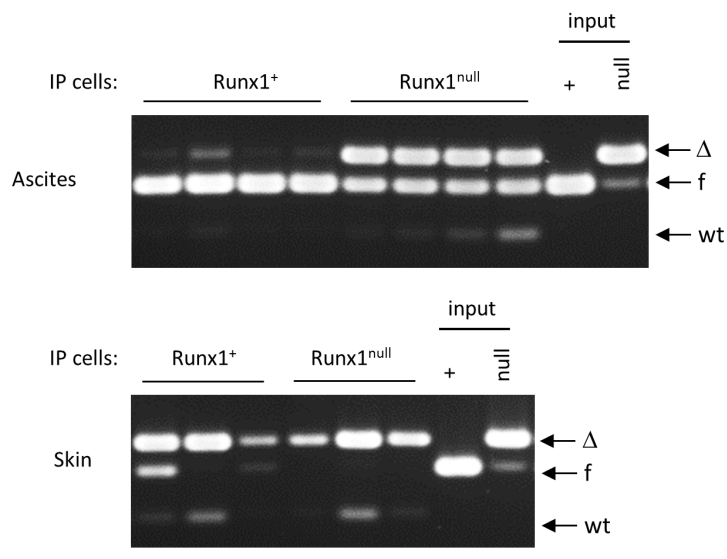

E $\mu$-Myc lymphoma cells are tumorigenic but circulating tumor cells display increased sensitivity to dexamethasone

The unexpected survival of E $\mu$-Myc lymphoma cell lines after Runxl excision in vitro led us to consider whether Runx 1 is required for lymphoma re-establishment in vivo. This was tested by inoculation of NOD-SCID/ $\gamma \mathrm{C}^{\text {null }}$ (NSG) mice with cell lines with and without excision of Runxl (Figure 8). Retrospective analysis showed that the Runx1-excised input cells had a small residual fraction of non-excised cells, while the non-excised input cells were virtually pure (Figure 8A). Notably, the nonexcised cells appeared to have a significant advantage in cells obtained from ascites but not in tumors that arose within the skin at the injection site, where mainly excised cells were observed. As these mice were not treated with $\mathrm{pIpC}$, the non-excised cells had clearly undergone spontaneously induced deletion in the skin tumor deposits. While this phenomenon may also reflect local production of endogenous IFN $\beta$ in skin e.g. by plasmacytoid dendritic cells [37] the key observation for this study is that tumors can develop in vivo with no detectable Runx1. This analysis also shows that there is a strong selective advantage for retention of Runx 1 in cells growing in suspension in the peritoneal cavity.

We also tested the effects of administration of dexamethasone on tumor formation. The most striking observation here was in circulating cells in blood, where dexamethasone treatment had a much greater effect in eliminating excised cells compared to their non-excised counterparts (Figure 8B). This observation illustrates the fact that the growth requirements of cells in vivo cannot be fully elucidated in vitro and suggests that free cells

\section{B}

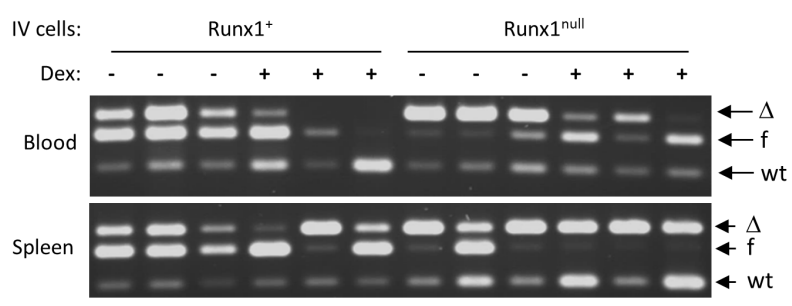

Figure 8: $\boldsymbol{R u n x}^{\text {null }}$ lymphoma cells are tumorigenic but are out-competed by $R$ unx $\boldsymbol{1}^{\text {flft }}$ cells in ascitic fluid and in the blood of in dexamethasone-treated mice. A. Runx 1 excision PCR on genomic DNA from vehicle control (Runx $\left.1^{+}\right)$or IFN $\beta$-treated (Runx $1^{\text {null })} 3$ s cell line cells ("input"), and from cells from ascites fluid (upper panel) and tumors in skin (lower panel) derived from 4 mice transplanted IP with each of the input cell types. B. Runx1 excision PCR on genomic DNA of cells derived from blood and spleen of 12 mice comprising 6 mice transplanted intravenously with $R u n x 1^{+}\left(3 \mathrm{~s}^{+}\right)$and 6 with Runx $I^{\text {null }}$ (3s-) cells, and 3 mice from each of these groups treated with dexamethasone or vehicle control as detailed in Materials and Methods. 
in circulation are most dependent on Runx 1 for their survival. Notably, some splenic lymphomas appeared to consist of exclusively Runx $1^{\text {null }}$ cells (Figure 8B, lower panel), again indicating attenuation of Runx1-dependency compared to primary lymphomas.

\section{DISCUSSION}

Previous studies have shown that ectopic expression of the Runx genes as a result of retroviral insertional mutagenesis or transgenic over-expression is potently synergistic with over-expressed Myc or loss of p53 in lymphomagenesis [9-11, 38, 39]. The present study shows that basal expression of the normal Runxl gene is vital for maintenance of primary Myc-driven lymphoma in vivo and that this dependence is stronger than in normal lymphoid cells, providing evidence of oncogene addiction in vivo. Surprisingly, lymphoma-derived cell lines were able to proliferate indefinitely and remained tumorigenic after complete excision of Runx 1. This is a telling observation, as it demonstrates that Runx 1 is not merely a structural component of the transcriptional apparatus that confers B-cell identity and sustains viability. However, Runx $1^{\text {null }}$ lymphoma cells displayed growth impairment compared to Runx 1 non-excised controls and were hypersensitive to DNA damaging agents and glucocorticoids. On transplantation, cells retaining Runx 1 also had a selective advantage when growing as non-adherent cells in the peritoneal cavity and as circulating cells in the blood of mice treated with glucocorticoid. These observations suggest that Runx $1^{\text {null }}$ cells may be partially protected by supportive sites of high cell density in vivo.

The ability of $\mathrm{p} 53^{\text {null }}$ E $\mu$-Myc lymphoma cell lines to survive Runxl deletion suggested a possible functional link whereby Runx1 protects against Mycdriven induction of p53 and/or downstream responses, and becomes superfluous after loss of the intact Tp53 allele during in vitro establishment. However, reintroduction of a temperature-sensitive p53 expression construct (Val135) into cell lines did not discriminate between Runx1 positive and negative cells, which succumbed to apoptosis with similar kinetics after temperature shift with or without irradiation. It is conceivable that another change, secondary to Trp53 allele loss, allows the established cells to survive without Runx1. This hypothesis is consistent with the observation that the Trp53 $3^{\text {null }}$ blast cell fraction in vivo showed substantial retention of the intact Runx 1 allele. However, we cannot exclude the possibility that ectopic p53 in vitro fails to recapitulate fully the behaviour of endogenous p53 in vivo. For example, we were surprised to observe a lack of induction of detectable $\mathrm{CDKN} 1 \mathrm{~A} / \mathrm{p} 21^{\text {Waf1 }}$ protein expression in response to irradiation and p53 activation. This observation implies that established E $\mu$-Myc lymphoma cells may have lost the capacity to undergo cell cycle arrest in response to p53 induction and choose cell death as the default pathway.
This phenomenon could account for the increased selection against wild-type p53 in cultured lymphoma cells compared to their in vivo counterparts [14].

The cell-type specific regulatory processes controlled by the Runx transcription factors are underlined by transcriptome analysis of E $\mu$-Myc lymphoma cells before and after Runxl excision, which revealed many changes that were not evident in control Runx $1^{\text {wt } / w t}$ lymphoma cells with inducible Cre expression. The Runx1 gene expression signature we observed in E $\mu-\mathrm{Myc}$ lymphoma cells was significantly enriched for regulators of lymphocyte proliferation, survival and differentiation, with changes consistent with the observed growth advantage and chemo-resistance associated with intact Runx1 expression.

The marked up-regulation of Rag1 and Rag2 after Runxl deletion is of particular interest. These genes are regulated in a complex, lineage-specific manner in $\mathrm{T}$ - and B-cells and undergo waves of expression during B-lymphocyte development [40]. The promoters of both genes harbour multiple Runx binding sites, while further Runx motifs are essential for the function of an intergenic Rag silencer in T-cells which is over-ridden in double positive thymocytes by an anti-silencer upstream of Rag2 [41]. We also noted strong inverse correlations between $R U N X 1$ and $R A G 1 / R A G 2$ mRNA expression in a panel of human leukemias and lymphomas. This is interesting in light of evidence that driver mutations are frequently induced by aberrant RAG activity in $\mathrm{t}(12 ; 21)$ TELRUNX1 leukemias [42] which express unusually high levels of $R A G 1$, but also in other genotypes that have no known lesion in RUNX1 [43, 44]. The weaker correlation between RUNX1 and $R A G$ expression in $\mathrm{t}(12 ; 21)$ leukemias may be an artefact of the detection of mRNA for both TEL-RUNX1 and the untranslocated RUNX1 allele but may also be a function of direct interference with $R A G$ repression by the fusion oncoprotein. Moreover, the increased incidence of T-cell lymphomas in ENU-treated chimeric mice [17] and the occurrence of apparent lossof-function RUNX1 mutations in a subset of ALLs [20] might be explained at least in part by dysregulation of recombinase gene expression.

We noted very little overlap with changes associated with Runx 1 deficiency in murine haematopoietic precursor cells where ribosomal biogenesis was implicated recently as a Runx1-directed function [45]. Apart from their separation in the differentiation hierarchy, E $\mu-\mathrm{Myc}$ cells differ from HPSCs in over-expression of Myc, a known driver of ribosome biogenesis [46]. It is therefore conceivable that the effect of Runx 1 deletion on ribosomal gene expression in HSPCs is mediated indirectly through loss of signalling to Myc. We also noted diametrically opposite effects of Runx1 deficiency on responses to DNA damage, where HSPCs were reported to display increased resistance [47], while we noted increased sensitivity of Runx $1^{\text {null }}$ E $\mu$-Myc cells. While this difference might be 
related to cell transformation, the relative permissiveness to Runx 1 deletion of the myeloid compartment in normal spleen suggests that lineage-specific factors are likely to be involved. Moreover, the increased fragility of Mycdriven lymphoma cells lacking Runxl indicates that targeting of Runx pathways is likely to be of therapeutic benefit in the context of Myc-driven lymphoma. We also noted little overlap with the mitotic checkpoint signature observed after knockdown of RUNX1 in Kasumi $t(8 ; 21)$ AML cells [31]. While lineage-specific differences may again be invoked to explain this discrepancy, the AML cells also express the RUNX1-ETO fusion protein which is likely to modulate at least some of the key promoters and enhancers vacated by RUNX1 knockdown.

The finding that basal Runxl activity is critical for Myc-driven lymphoma maintenance in vivo and that dependence is only partially attenuated in established cell lines lacking p53 is encouraging for ongoing efforts to target the Runx genes and their downstream effectors in cancer therapy [48, 49]. Moreover, the increased sensitivity of Runxl-deleted cells to components of standard chemotherapeutic regimens in current use for lymphoma therapy suggests that these may be combined with Runx inhibition for greater efficacy.

\section{MATERIALS AND METHODS}

\section{Generation of transgenic crosses and animal experiments}

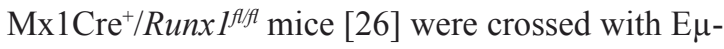
Myc mice and $p 53^{-/-}$mice to produce highly tumour-prone

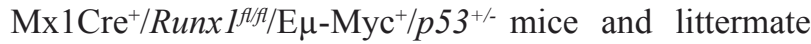
controls lacking Mx1Cre and/or E $\mu$-Myc. Litters were treated at two weeks of age with $8.5 \mathrm{mg} / \mathrm{kg}$ pIpC injected intraperitoneally (IP; two injections two days apart) or left untreated; animals were humanely culled when they showed signs of tumour development. Runx $1^{\text {wt }}$ controls

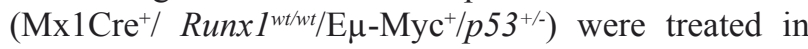
the same way. Adult E $\mu-\mathrm{Myc}^{-} /$Runx $^{f l / f}$ mice were treated with 6 injections of $600 \mu \mathrm{g}$ pIpC 2-3 days apart at 5 weeks of age. Transplantation assays were performed in NOD/ $\mathrm{SCID} / \gamma \mathrm{Cn}^{\text {null }}$ (NSG) mice, which were transplanted IP or intravenously (IV) with $5 \times 10^{6}$ Runx $^{+}$or Runx $1^{\text {null }}$ cells; IV-transplanted mice were treated with $20 \mathrm{mg} /$ $\mathrm{kg}$ Dexadresone ${ }^{\mathbb{R}}$ IP or vehicle control daily, MondayFriday for 3 weeks and 5-10 $\mu 1$ blood for flow cytometric analysis of $\mathrm{B} 220^{+}$cell counts were removed weekly by tail-tipping. Animal protocols used in this work were evaluated and approved by the University of Glasgow Ethics and Welfare Committee and were carried out under Home Office License (approval granted September 2012, license number PPL 60/4408) as governed by the Animal Scientific Procedures Act, 1986.

\section{Statistical analysis}

Survival curves were compared using the Wilcoxon rank sum test. All other statistical comparisons were performed using the Student's $t$-test.

\section{Flow cytometry and cell sorting}

Phenotyping of spleen cells was performed using the following antibodies: anti-B220-phycoerythrin, anti-CD4-phycoerythrin, anti-Mac1-PerCPCy5.5 (all BD Biosciences) and anti-CD8-FITC (Serotec). Spleen cell suspensions in PBS $+0.1 \%$ BSA (wash buffer) were stained with combinations of antibodies or isotype controls for 30 minutes at $4^{\circ} \mathrm{C}$, red cells were lysed using Pharmlyse (BD Biosciences) and cells were analysed using an Accuri C6 flow cytometer and Cflow Sampler software (BD Biosciences). Analysis of activated caspase 3 expression was performed by flow cytometry using the PE Active Caspase 3 Apoptosis Kit (BD Biosciences) according to manufacturer's instructions. Sorting of spleen lymphoid and myeloid cells was performed using a combination of anti-B220-phycoerythrin and anti-CD3phycoerythrin to identify lymphoid cells and anti-Mac1PerCPCy5.5 to identify myeloid cells. Sorting of blast cells from primary lymphomas was performed by staining cells with anti-B220-phycoerythin and anti-CD45-FITC; in the $\mathrm{B} 220^{+}$population, blast cells were identified using CD45 and SSC as reported in [27]. All sorting was performed using a FACSAria (BD Biosciences).

\section{Genomic DNA extraction and PCR}

Genomic DNA was extracted from cell lines using the DNeasy kit (Qiagen) and from tissues using the illustra Nucleon BACC2 DNA extraction kit (GE Life Sciences). Determination of DNA concentration was carried out using a Nanodrop 2000 (Thermo Scientific, Walatham, MA. USA). Analysis of Runxl excision in primary cells/tissues and cell lines was carried out using previously described primers and cycling conditions [50]; master mix was prepared with 2x ReddyMix, $1.6 \mu \mathrm{M}$ each primer and 10ng template DNA. Validation of this assay for quantitative determination of Runxl excision was performed by analysing excision in standards containing mixtures of $0-100 \%$ excised cells. PCR for p53 wild-type and null alleles was performed using 20ng template DNA, 2x ReddyMix (ThermoFisher Scientific) and primers directed against p53 intron 4 (WP53: GTGTTTCATTAGTTCCCCAC), exon 5 (UP3: ATGGTGGGGGCAGCGTCTCA), and the null allele (NP5: CGGTCTTGTCGATCAGGATG); cycling conditions were 5 minutes at $94^{\circ} \mathrm{C}, 35$ cycles of 1 minute at $94^{\circ} \mathrm{C}, 1$ minute at $55^{\circ} \mathrm{C}$ and 1 minute at $72^{\circ} \mathrm{C}$, then 7 
minutes at $72^{\circ} \mathrm{C}$, generating PCR products of $242 \mathrm{bp}$ (p53 wt allele) or $470 \mathrm{bp}$ (p53 null allele). All PCR products were separated on a 1.5 or $2 \%$ agarose gel and visualised with ethidium bromide and UV transillumination. Densitometry was carried out using ImageJ software (http://imagej.nih.gov/ij/); images shown were adusted only for contrast.

\section{Cell culture, constructs and retroviral transductions}

The $3 \mathrm{~s}, 6 \mathrm{~s}$ and $44 \mathrm{~s}$ cell lines were established from spleen tissue from primary lymphomas in $\mathrm{Mx} 1 \mathrm{Cre}^{+} /$ Runx $1^{f / f /} / \mathrm{E} \mu-\mathrm{Myc} / p 53^{+/}$transgenic mice and grown in RPMI 1640 supplemented with 10\% FCS, 100U/ml penicillin and streptomycin, $2 \mathrm{mM}$ L-glutamine and $50 \mu \mathrm{M}$ 2-mercaptoethanol (complete RPMI; all reagents from Life Technologies). Paired Runx $1^{\text {null }}$ and Runx $1^{+}$cells were created from Runx $1^{\text {flff }}$ parental cell lines by treatment with 5-50U/ml IFN $\beta$ (R\&D Systems) or vehicle control (PBS+0.1\% BSA); Runx 1 excision in IFN $\beta$-treated lines was confirmed by Runx 1 excision PCR. The $\mathrm{p} 53^{\mathrm{V} 135}$-GFP was constructed by ligating the $1.4 \mathrm{~kb}$ EcoR 1 fragment containing murine $\mathrm{p} 53^{\mathrm{V} 135}$ [51] into the Mig-R1 vector [52]. Viral supernatants were prepared following transient transfection of GP86+E or 293T cells respectively and used to infect $3 \mathrm{~s}$ cells as described previously [53]. Infected cells were sorted for $\mathrm{GFP}^{+}$cells. Doubling time assays were performed in 12-well cell culture plates with $2 \times 10^{5} \mathrm{cell} / \mathrm{s} / \mathrm{ml}$ and counted 24 hours after initiation of culture; doubling times were calculated using the formula $\mathrm{T}_{\mathrm{d}}=\mathrm{t}_{\mathrm{i}} \times\left(\log (2) / \log \left(\mathrm{q}_{2}-\mathrm{q}_{1}\right)\right)$ where $\mathrm{T}_{\mathrm{d}}=$ doubling time, $\mathrm{t}_{\mathrm{i}}=$ incubation time, $\mathrm{q}_{1}=$ number of cells at start of assay and $\mathrm{q}_{2}=$ number of cells at end of assay. Competition assays were performed by mixing equal numbers of excised and non-excised cells; cells were cultured in duplicate in complete RPMI, passaging three times per week, returning $10^{5}$ cells to $10 \mathrm{ml}$ culture at each passage; Runx 1 excision in the culture was monitored weekly by Runx 1 excision PCR. Ethanol, doxorubicin (Stratech Scientific \#S1208 $10 \mathrm{mM}$ in DMSO) or dexamethasone (Sigma D2915) treatment of pairs of excised and non-excised cell lines was carried out in 12-well plates using $2 \times 10^{5}$ cells $/ \mathrm{ml}$ and with the addition of ethanol $(0.8 \%)$, doxorubicin $(1.0 \mu \mathrm{M})$ or dexamethasone $(1.0 \mu \mathrm{M})$. Single cell cloning of cell lines was performed by partially excising Runx 1 by sub-optimal IFN $\beta$ treatment and sorting single cells into 96-well plates in complete RPMI; growing clones were transferred to larger culture dishes until sufficient cells to analyse were obtained.

\section{RNA extraction and microarray analysis}

Total RNA was isolated by RNeasy kit (Qiagen, Manchester, UK) from three cultures each of established lymphoma lines 3s $\left(\mathrm{Mx} 1 \mathrm{Cre}^{+} /\right.$Runx $\left.^{f l f l f} / \mathrm{E} \mu-\mathrm{Myc}^{+} / p 53^{+/-}\right)$ and 30s $\left(\mathrm{Mx} 1 \mathrm{Cre}^{+} / R u n x 1^{w t / w t} / \mathrm{E} \mu-\mathrm{Myc}^{+} / p 53^{+/}\right)$, treated with and without IFN $\beta$ to excise endogenous Runx I (Figure 4A). RNA was tested for quality on the Agilent 2100 Bioanalyser (Agilent Technologies, Stockport, UK) and NanoDrop 2000 (Thermo Scientific, Walatham, MA. USA) before screening against Affymetrix GeneChip Mouse Transcriptome Array 1.0 (High Wycombe, UK, 2014) by ATLAS Biolabs (Berlin, Germany) according to standard protocols. RMA normalisation followed by probe annotation and statistical analysis to generate $p$-values and fold changes was performed using Partek Genomics Suite 6.6 (Partek Inc., St.Louis, MO, USA). Microarray data are available at the Gene Expression Omnibus (GEO) repository, accession number GSE78001.

\section{Quantitative real-time PCR}

cDNA was prepared from $1 \mu \mathrm{g}$ aliquots of RNA using a Quantitect Reverse Transcription kit (Qiagen) and diluted 1 in 20 in DEPC-treated water to give a working stock. For quantitative real-time PCR, 12.5ng aliquots of cDNA were amplified in triplicate on an ABI 7500 realtime PCR system using Power SYBR Green PCR master Mix (Thermo Fisher Scientific, UK), and primers for murine Bcl11a, Cd55, Daf2, Il7r, Nckap1, Ptpn22, Prkcb, Rag1, Rag2 or endogenous control 18S rRNA (Qiagen QuantiTect Primer Assays). Relative quantification was carried out and calibrated to vector control samples where appropriate. Data were analysed using the standard software for the ABI 7500 real-time PCR system.

\section{Western blotting and antibodies}

Preparation of whole cell protein extracts was performed as described previously [54]. Samples equivalent to $50 \mu \mathrm{g}$ of protein (Bio-Rad protein assay) were resolved on $8-12 \%$ SDS polyacrylamide gels and transferred to enhanced chemiluminescence (ECL; Fischer Scientific), nitrocellulose membranes. The antibodies used were $\alpha$ Runx1 (\#8229 New England Biolabs), $\alpha$ p53(FL393), $\alpha$ p21 ${ }^{\mathrm{WAF} 1}, \alpha$ Actin (sc-6243, sc-471 and sc-1616, Santa Cruz Biotechnology) and $\alpha$ CDKN2A/ p19ARF (ab80, Abcam). Positive controls were as follows: Runx1 (NIH3T3 transduced with pBabeRunx1 P1 [15], p53 and p21 ${ }^{\text {WAF1 }}$ (UVC-treated wild type MEF extract), p19 ${ }^{\text {ARF }}$ (SV3T3 cell extract).

\section{CONCLUSIONS}

Primary lymphoma cells from E $\mu$-Myc mice show evidence of addiction to Runxl in vivo, but become permissive for deletion in vitro. Loss of p53 function appears to be necessary but not sufficient for this process. In this context Runx1 controls a network of 
genes involved in lymphocyte proliferation, survival and differentiation, shedding light on its dualistic behaviour in lymphomagenesis. While the ability of Myc-driven lymphoma cells to grow in the absence of Runx 1 is surprising, their impaired proliferation and increased chemo-sensitivity validates Runx 1 function as a candidate target in future combination therapies.

\section{ACKNOWLEDGMENTS AND FUNDING}

This work was supported by a joint programme grant from Bloodwise (grant number 13046) and Cancer Research UK (grant number A11951). We thank Nancy Speck (University of Pennsylvania) for kind provision of Runx $1^{f l f t}$ mice. We thank Jennifer Cassels (University of Glasgow) for helpful assistance with cell sorting.

\section{CONFLICTS OF INTEREST}

The authors disclose no potential conflicts of interest.

\section{REFERENCES}

1. North T, Gu TL, Stacy T, Wang Q, Howard L, Binder M, Marin-Padilla M, Speck NA: Cbfa2 is required for the formation of intra-aortic hematopoietic clusters. Development 1999;126:2563-2575.

2. Levanon D, Groner Y: Structure and regulated expression of mammalian RUNX genes. Oncogene 2004;23:42114219.

3. Ito Y: RUNX genes in development and cancer: regulation of viral gene expression and the discovery of RUNX family genes. Adv Cancer Res 2008;99:33-76.

4. Ito Y, Bae SC, Chuang LS: The RUNX family: developmental regulators in cancer. Nat Rev Cancer 2015; 15:81-95.

5. Blyth K, Cameron ER, Neil JC: The RUNX genes: gain or loss of function in cancer. Nat Rev Cancer 2005;5:376-387.

6. Mikkers H, Allen J, Knipscheer P, Romeijn L, Hart A, Vink E, Berns A: High-throughput retroviral tagging to identify components of specific signaling pathways in cancer. Nat Genet 2002;32:153-159.

7. Stewart M, Terry A, Hu M, O'Hara M, Blyth K, Baxter E, Cameron E, Onions DE, Neil JC: Proviral insertions induce the expression of bone-specific isoforms of PEBP2alphaA (CBFA1): evidence for a new myc collaborating oncogene. Proc Natl Acad Sci U S A 1997;94:8646-8651.

8. Wotton S, Stewart M, Blyth K, Vaillant F, Kilbey A, Neil JC, Cameron ER: Proviral insertion indicates a dominant oncogenic role for Runx1/AML-1 in T-cell lymphoma. Cancer Res 2002;62:7181-7185.

9. Stewart M, Mackay N, Cameron ER, Neil JC: The common retroviral insertion locus Dsi1 maps 30 kilobases upstream of the P1 promoter of the murine Runx3/Cbfa3/Aml2 gene. J Virol 2002;76:4364-4369.

10. Blyth K, Terry A, Mackay N, Vaillant F, Bell M, Cameron ER, Neil JC, Stewart M: Runx2: a novel oncogenic effector revealed by in vivo complementation and retroviral tagging. Oncogene 2001;20:295-302.

11. Vaillant F, Blyth K, Terry A, Bell M, Cameron ER, Neil J, Stewart M: A full-length Cbfa1 gene product perturbs T-cell development and promotes lymphomagenesis in synergy with myc. Oncogene 1999;18:7124-7134.

12. Blyth K, Slater N, Hanlon L, Bell M, Mackay N, Stewart M, Neil JC, Cameron ER: Runx1 promotes B-cell survival and lymphoma development. Blood Cells Mol Dis 2009;43:1219.

13. Vaillant F, Blyth K, Andrew L, Neil JC, Cameron ER: Enforced expression of Runx 2 perturbs $\mathrm{T}$ cell development at a stage coincident with beta-selection. J Immunol 2002;169:2866-2874.

14. Blyth K, Vaillant F, Hanlon L, Mackay N, Bell M, Jenkins A, Neil JC, Cameron ER: Runx2 and MYC collaborate in lymphoma development by suppressing apoptotic and growth arrest pathways in vivo. Cancer Res 2006;66:21952201.

15. Wotton SF, Blyth K, Kilbey A, Jenkins A, Terry A, Bernardin-Fried F, Friedman AD, Baxter EW, Neil JC, Cameron ER: RUNX1 transformation of primary embryonic fibroblasts is revealed in the absence of p53. Oncogene 2004;23:5476-5486.

16. Blyth K, Terry A, O'Hara M, Baxter EW, Campbell M, Stewart M, Donehower L, Onions DE, Neil JC, Cameron ER: Synergy between a human c-myc transgene and p53 null genotype in murine thymic lymphomas: contrasting effects of homozygous and heterozygous p53 loss. Oncogene 1995;10:1717-1723.

17. Kundu M, Compton S, Garrett-Beal L, Stacy T, Starost MF, Eckhaus M, Speck NA, Liu PP: Runx1 deficiency predisposes mice to T-lymphoblastic lymphoma. Blood 2005; 106:3621-3624.

18. Niini T, Vettenranta K, Hollmen J, Larramendy ML, Aalto Y, Wikman H, Nagy B, Seppanen JK, Ferrer SA, Mannila H, Saarinen-Pihkala UM, Knuutila S: Expression of myeloid-specific genes in childhood acute lymphoblastic leukemia - a cDNA array study. Leukemia 2002;16:22132221.

19. Harewood L, Robinson H, Harris R, Al-Obaidi MJ, Jalali GR, Martineau M, Moorman AV, Sumption N, Richards S, Mitchell C, Harrison CJ: Amplification of AML1 on a duplicated chromosome 21 in acute lymphoblastic leukemia: a study of 20 cases. Leukemia 2003;17:547-553.

20. Della GG, Palomero T, Perez-Garcia A, AmbesiImpiombato A, Bansal M, Carpenter ZW, De KK, Sole $\mathrm{X}, \mathrm{Xu} \mathrm{L}$, Paietta E, Racevskis J, Wiernik PH, Rowe JM, Meijerink JP, Califano A, Ferrando AA: Reverse engineering of TLX oncogenic transcriptional networks 
identifies RUNX1 as tumor suppressor in T-ALL. Nat Med 2012;18:436-440.

21. Osato M, Yanagida M, Shigesada K, Ito Y: Point mutations of the RUNx1/AML1 gene in sporadic and familial myeloid leukemias. Int J Hematol 2001;74:245-251.

22. Song WJ, Sullivan MG, Legare RD, Hutchings S, Tan X, Kufrin D, Ratajczak J, Resende IC, Haworth C, Hock R, Loh M, Felix C, Roy DC, Busque L, Kurnit D, Willman C, Gewirtz AM, Speck NA, Bushweller JH, Li FP, Gardiner K, Poncz M, Maris JM, Gilliland DG: Haploinsufficiency of CBFA2 causes familial thrombocytopenia with propensity to develop acute myelogenous leukaemia. Nat Genet 1999;23:166-175.

23. Chen MJ, Yokomizo T, Zeigler BM, Dzierzak E, Speck NA: Runx1 is required for the endothelial to haematopoietic cell transition but not thereafter. Nature 2009;457:887-891.

24. Eischen CM, Weber JD, Roussel MF, Sherr CJ, Cleveland JL: Disruption of the ARF-Mdm2-p53 tumor suppressor pathway in Myc-induced lymphomagenesis. Genes Dev 1999;13:2658-2669.

25. Hsu B, Marin MC, El-Naggar AK, Stephens LC, Brisbay $\mathrm{S}, \mathrm{McDonnell} \mathrm{TJ}$ : Evidence that c-myc mediated apoptosis does not require wild-type p53 during lymphomagenesis. Oncogene 1995;11:175-179.

26. Growney JD, Shigematsu H, Li Z, Lee BH, Adelsperger J, Rowan R, Curley DP, Kutok JL, Akashi K, Williams IR, Speck NA, Gilliland DG: Loss of Runx1 perturbs adult hematopoiesis and is associated with a myeloproliferative phenotype. Blood 2005;106:494-504.

27. Guo W, Lasky JL, Chang CJ, Mosessian S, Lewis X, Xiao Y, Yeh JE, Chen JY, Iruela-Arispe ML, Varella-Garcia $\mathrm{M}, \mathrm{Wu} \mathrm{H}$ : Multi-genetic events collaboratively contribute to Pten-null leukaemia stem-cell formation. Nature 2008;453:529-533.

28. Shimizu K, Yamagata K, Kurokawa M, Mizutani S, Tsunematsu Y, Kitabayashi I: Roles of AML1/RUNX1 in T-cell malignancy induced by loss of p53. Cancer Sci. 2013; 104:1033-8.

29. Abdueva D, Skvortsov D, Tavare S: Non-linear analysis of GeneChip arrays. Nucleic Acids Res 2006;34:e105.

30. Cai X, Gao L, Teng L, Ge J, Oo ZM, Kumar AR, Gilliland DG, Mason PJ, Tan K, Speck NA: Runx1 Deficiency Decreases Ribosome Biogenesis and Confers Stress Resistance to Hematopoietic Stem and Progenitor Cells. Cell Stem Cell 2015;17:165-177.

31. Ben-Ami O, Friedman D, Leshkowitz D, Goldenberg D, Orlovsky K, Pencovich N, Lotem J, Tanay A, Groner Y: Addiction of $\mathrm{t}(8 ; 21)$ and inv(16) acute myeloid leukemia to native RUNX1. Cell Rep 2013;4:1131-1143.

32. Papaemmanuil E, Rapado I, Li Y, Potter NE, Wedge DC, Tubio J, Alexandrov LB, Van LP, Cooke SL, Marshall J, Martincorena I, Hinton J, Gundem G, et al. RAG-mediated recombination is the predominant driver of oncogenic rearrangement in ETV6-RUNX1 acute lymphoblastic leukemia. Nat Genet 2014;46:116-125.

33. Haferlach T, Kohlmann A, Wieczorek L, Basso G, Kronnie GT, Bene MC, De VJ, Hernandez JM, Hofmann WK, Mills KI, Gilkes A, Chiaretti S, Shurtleff SA, Kipps TJ, Rassenti LZ, Yeoh AE, Papenhausen PR, Liu WM, Williams PM, Foa R: Clinical utility of microarray-based gene expression profiling in the diagnosis and subclassification of leukemia: report from the International Microarray Innovations in Leukemia Study Group. J Clin Oncol 2010;28:2529-2537.

34. Wang Z, Wei D, Xiao H: Methods of cellular senescence induction using oxidative stress. Methods Mol Biol 2013;1048:135-144.

35. Abraham J, Balbo S, Crabb D, Brooks PJ: Alcohol metabolism in human cells causes DNA damage and activates the Fanconi anemia-breast cancer susceptibility (FA-BRCA) DNA damage response network. Alcohol Clin Exp Res 2011;35:2113-2120.

36. Wotton S, Terry A, Kilbey A, Jenkins A, Herzyk P, Cameron E, Neil JC: Gene array analysis reveals a common Runx transcriptional programme controlling cell adhesion and survival. Oncogene 2008;27:5856-5866.

37. Gregorio J, Meller S, Conrad C, Di NA, Homey B, Lauerma A, Arai N, Gallo RL, Digiovanni J, Gilliet M: Plasmacytoid dendritic cells sense skin injury and promote wound healing through type I interferons. J Exp Med 2010;207:2921-2930.

38. Stewart M, Terry A, O'Hara M, Blyth K, Baxter E, Cameron E, Onions D, Neil JC: Proviral insertions induce the expression of bone-specific isoforms of PEBP2alphaA (CBFA1): evidence for a new myc collaborating gene. Proc Natl Acad Sci USA 1997;94:8646-8651.

39. Wotton S, Stewart M, Blyth K, Vaillant F, Kilbey A, Neil JC, Cameron ER: Proviral insertion indicates a dominant oncogenic role for Runx1/AML-1 in T-cell lymphoma. Cancer Res 2002;62:7181-7185.

40. Yu W, Misulovin Z, Suh H, Hardy RR, Jankovic M, Yannoutsos N, Nussenzweig MC: Coordinate regulation of RAG1 and RAG2 by cell type-specific DNA elements 5' of RAG2. Science 1999;285:1080-1084.

41. Yannoutsos N, Barreto V, Misulovin Z, Gazumyan A, Yu W, Rajewsky N, Peixoto BR, Eisenreich T, Nussenzweig $\mathrm{MC}$ : A cis element in the recombination activating gene locus regulates gene expression by counteracting a distant silencer. Nat Immunol 2004;5:443-450.

42. Alexandrov LB, Nik-Zainal S, Wedge DC, Aparicio SA, Behjati S, Biankin AV, Bignell GR, Bolli N, Borg A, Borresen-Dale AL, Boyault S, Burkhardt B, Butler AP, et al. Signatures of mutational processes in human cancer. Nature 2013;500:415-421.

43. Mendes RD, Sarmento LM, Cante-Barrett K, Zuurbier L, Buijs-Gladdines JG, Povoa V, Smits WK, Abecasis M, Yunes JA, Sonneveld E, Horstmann MA, Pieters R, Barata JT, Meijerink JP: PTEN microdeletions in T-cell acute lymphoblastic leukemia are caused by illegitimate RAGmediated recombination events. Blood 2014;124:567-578. 
44. Navarro JM, Touzart A, Pradel LC, Loosveld M, Koubi M, Fenouil R, Le NS, Maqbool MA, Morgado E, Gregoire C, Jaeger S, Mamessier E, Pignon C, et al. Site- and allelespecific polycomb dysregulation in T-cell leukaemia. Nat Commun 2015;6:6094.

45. Cai X, Gao L, Teng L, Ge J, Oo ZM, Kumar AR, Gilliland DG, Mason PJ, Tan K, Speck NA: Runx1 Deficiency Decreases Ribosome Biogenesis and Confers Stress Resistance to Hematopoietic Stem and Progenitor Cells. Cell Stem Cell 2015;17:165-177.

46. van Riggelen J., Yetil A, Felsher DW: MYC as a regulator of ribosome biogenesis and protein synthesis. Nat Rev Cancer 2010;10:301-309.

47. Venkata JK, An N, Stuart R, Costa LJ, Cai H, Coker W, Song JH, Gibbs K, Matson T, Garrett-Mayer E, Wan Z, Ogretmen B, Smith C, Kang Y: Inhibition of sphingosine kinase 2 downregulates the expression of c-Myc and Mcl-1 and induces apoptosis in multiple myeloma. Blood 2014;124:1915-1925.

48. Marugan JJ, Xiao J, Zheng W, Southall N, Dehdashti S, Cunningham L, Liu PP: ML223: A Small Molecule Probe With In Vivo Activity Against Acute Myeloid Leukemia Subtype M4Eo. Probe Reports from the NIH Molecular Libraries Program [Internet]. Bethesda (MD): National Center for Biotechnology Information (US); 2010-2011.

49. Illendula A, Pulikkan JA, Zong H, Grembecka J, Xue L, Sen S, Zhou Y, Boulton A, Kuntimaddi A, Gao Y, Rajewski RA, Guzman ML, Castilla LH, Bushweller JH: Chemical biology. A small-molecule inhibitor of the aberrant transcription factor CBFbeta-SMMHC delays leukemia in mice. Science 2015;347:779-784.

50. Chen MJ, Yokomizo T, Zeigler BM, Dzierzak E, Speck NA: Runx 1 is required for the endothelial to haematopoietic cell transition but not thereafter. Nature 2009;457:887-891.

51. Michalovitz D, Halevy O, Oren M: Conditional inhibition of transformation and of cell proliferation by a temperaturesensitive mutant of p53. Cell 1990;62:671-680.

52. Pear WS, Miller JP, Xu L, Pui JC, Soffer B, Quackenbush RC, Pendergast AM, Bronson R, Aster JC, Scott ML, Baltimore D: Efficient and rapid induction of a chronic myelogenous leukemia-like myeloproliferative disease in mice receiving P210 bcr/abl-transduced bone marrow. Blood 1998;92:3780-3792.

53. Blyth K, Slater N, Hanlon L, Bell M, Mackay N, Stewart M, Neil JC, Cameron ER: Runx1 promotes B-cell survival and lymphoma development. Blood Cells Mol Dis 2009;43:1219.

54. Wotton S, Terry A, Kilbey A, Jenkins A, Herzyk P, Cameron E, Neil JC: Gene array analysis reveals a common Runx transcriptional programme controlling cell adhesion and survival. Oncogene 2008;27:5856-5866. 